\title{
ВИЗНАЧЕННЯ АРБУТИНУ В ГРУШІ ЗВИЧАЙНОЇ ЛИСТІ СОРТІВ ЛИМОНКА, ЛІСОВА КРАСУНЯ ТА НОЯБРСЬКА
}

Вступ. Цистит - одна з доволі частих нозологічних фрорм інфекційно-запальних захворювань сечовивідних шляхів. Розповсюдженість гострого циститу в Україні становить 314 на 100 тис. населення, хронічного циститу - 135 на 100 тис. населення. Для лікування даного захворювання успішно використовують лікарську рослинну сировину, що містить арбутин і гідрохінон, зокрема сировину груші звичайної.

Мета дослідження - виявити і визначити кількісний вміст арбутину в груші звичайної листі сортів Лимонка, Лісова красуня та Ноябрська.

Методи дослідження. Об'єктом дослідження було груші звичайної листя сортів Лимонка, Лісова красуня та Ноябрська. Виявлення арбутину проводили за допомогою хімічних реакцій і хроматографрії в тонкому шарі сорбенту. Його кількісний вміст визначали спектрофротометричним методом при довжині хвилі 455 нм за методикою Державної Фармакопеї України.

Результати й обговорення. У результаті проведення хімічних реакцій і хроматографрічного аналізу в груші звичайної листі сортів, які вивчали, встановлено наявність арбутину. Вміст арбутину, який було визначено спектрофотометричним методом, у груші звичайної листі сортів Лимонка, Лісова красуня та Ноябрська становив 1,07, 3,32 і 3,01 \% відповідно.

Висновки. У груші звичайної листі сортів Лимонка, Лісова красуня та Ноябрська встановлено наявність і визначено вміст арбутину, який становив 1,07, 3,32 та 3,01 \% відповідно. Одержані експериментальні дані буде використано при стандартизації груші звичайної листя, розробці методів контролю якості на досліджувану сировину, а також одержанні фрармакологічно активних субстанцій на ї̈ основі.

КЛЮЧОВІ СЛОВА: груша звичайна; арбутин; якісний та кількісний аналіз; хроматографрія; спектрометрія.

ВСТУП. Інфекції сечовивідних шляхів належать до найпоширеніших захворювань. Вони зумовлені запальним процесом, передусім бактеріального генезу, що розвивається в різних анатомічних ділянках сечовидільної системи [1]. Цистит - одна з доволі частих нозологічних форм інфекційно-запальних захворювань сечовивідних шляхів. Найчастіше цю патологію діагностують у жінок. Цистит може проявлятися ів чоловіків будь-якого віку [2]. Розповсюдженість гострого циститу в Україні становить 314 на 100 тис. населення, хронічного циститу - 135 на 100 тис. населення [3]. Близько 40-50 \% жінок хоча б один раз за життя хворіли на гострий цистит, у 20-30 \% спостерігали рецидив протягом наступних 3-4 місяців. Близько 1020 \% із них страждають від рецидивного циститу

( ) О. М. Новосел, В. С. Кисличенко, А. І. Федосов, Л. М. Андрюкова, А. А. Волошина, 2020. протягом усього життя. Це значно впливає на якість життя жінок і має значний соціальний вплив на суспільство [2].

Зростання резистентності збудників інфрекцій сечовивідних шляхів зумовлює зниження ефективності антибіотикотерапії. Це обумовлює використання лікарської рослинної сировини, яка має антимікробну, фітонцидну, протизапальну, сечогінну, спазмолітичну, знеболювальну дію, в терапії циститу [4]. Для цього успішно застосовують сировину, що містить арбутин і гідрохінон . Дослідження Н. Л. Волобой показали, що при ентеральному введенні арбутин і гідрохінон проявляють діуретичну активність, яка більш вираженав арбутину [5, 6]. Крім того, встановлено, що гідрохінон має виражену антибактеріальну дію відносно грамнегативних мікроорганізмів, тоді як антимікробна дія арбутину проявляється тільки після гідролізу [6, 7]. Також арбутин і гідро- 
хінон мають антиоксидантні та прооксидантні властивості, причому гідрохінон більшою мірою є антиоксидантом, а арбутин-прооксидантом [8].

Перспективним джерелом одержання арбутину та гідрохінону є груша звичайна. Раніше на кафредрі хімії природних сполук профр. В. С. Кисличенко і доц. О. М. Новосел провели фрармакогностичне дослідження дикорослої груші звичайної [9]. Оскільки груша широко культивується в Україні, доцільним є вивчення більш поширених її сортів.

Мета дослідження - виявити і визначити кількісний вміст арбутину в груші звичайної листі сортів Лимонка, Лісова красуня та Ноябрська.

МЕТОДИ ДОСЛІДЖЕННЯ. Об'єктом ДОслідження було обрано груші звичайної листя сортів Лимонка, Лісова красуня та Ноябрська.

Виявлення арбутину в сировині, яку вивчали, проводили за допомогою хімічних реакцій (кристалічний фреруму (II) сульсрат; 10 \% розчин натрію фоссрорно-молібденовокислого в кислоті хлористоводневій) і хроматографії в тонкому шарі сорбенту. Як рухому фразу використовували мурашину кислоту безводну $P$ - воду $P$ - етилацетат $P$ (6:6:88). Хроматограму обробляли розчином 10 г/л дихлорхінонхлориміду $P$ у метанолі $P$, потім - розчином 20 г/л натрію карбонату безводного $P$ [10-12].

Вміст арбутину визначали спектрофротометричним методом. Для цього здрібнену на порошок сировину в кількості 0,4 г (точна наважка) екстрагували 50 мл води при кип'ятінні на водяній бані протягом 30 хв. Витяжку охолоджували та кількісно переносили в мірну колбу місткістю 250 мл, доводячи об'єм розчину водою до позначки (вихідний розчин). До 5 мл вихідного розчину в ділильній лійці додавали 45 мл води, 1 мл 2 \% розчину амінопіразолону $P, 0,5$ мл розчину аміаку розведеного $P 2,1$ мл 8 \% розчину калію фериціаніду $P$, ретельно перемішували та витримували 5 хв. Водний шар послідовно обробляли трьома порціями, по 25 мл кожна, хлорофрорму $P$. Хлороформний шар фрільтрували крізь фрільтр у мірну колбу місткістю 100 мл, доводили об'єм розчину хлороформом до позначки та перемішували (випробовуваний розчин). Як розчин порівняння використовували розчин 0,015 г ФСЗ ДФУ арбутину в мірній колбі місткістю 100 мл, оброблений аналогічно випробовуваному розчину. Оптичну густину випробовуваного розчину та розчину порівняння вимірювали на спектрофротометрі “Optizen” при довжині хвилі 455 нм, застосовуючи як компенсаційну рідину хлорофрорм $P$. Вміст гідрохінон-похідних, у перерахунку на арбутин, у відсотках, обчислювали за орормулою:

$$
X=\frac{A \times m_{0} \times 2,5 \times P}{A_{0} \times m},
$$

де $A$ - оптична густина випробовуваного розчину при довжині хвилі 455 нм;

$A_{0}$ - оптична густина розчину порівняння при довжині хвилі 455 нм;

$m_{0}$ - маса наважки ФСЗ ДФУ арбутину, г;

$P$ - вміст арбутину безводного у ФСЗ ДФУ арбутину, \%;

m - маса наважки випробовуваної сировини, г [10].

РЕЗУЛЬТАТИ Й ОБГОВОРЕННЯ. ПОЗИТИВНі результати хімічних реакцій дозволили стверджувати, що в груші звичайної листі сортів, які вивчали, наявний арбутин. У результаті проведення хроматографічного аналізу у витяжках із груші звичайної листя сортів Лимонка, Лісова красуня та Ноябрська було виявлено не менше 4-х речовин. Після порівняння величин Rf та забарвлення плям після обробки хроматограми реактивами проявлення ідентифіковано арбутин. Результати визначення кількісного вмісту арбутину в сировині наведено в таблиці.

Як свідчать результати кількісного аналізу, наведені в таблиці, вміст арбутину в груші звичайної листі сорту Лимонка становив 1,07 \%, сорту Лісова красуня - 3,32 \%, сорту Ноябрська 3,01 \%. Дані проведеного дослідження показали, що вміст арбутину в сортах Лісова красуня та Ноябрська майже однаковий - 3,32 і 3,01 \% відповідно, тоді як у сорті Лимонка вміст цієї речовини у 3 рази нижчий. Порівнюючи одержані результати з попередніми (вміст арбутину в груші звичайної листі - 1,89\%), можна зробити висновок, що найбільш перспективними джерелами арбутину є груші звичайної листя сортів Лісова красуня та Ноябрська.

Таблиця - Результати кількісного визначення арбутину в груші звичайної листі сортів Лимонка, Лісова красуня та Ноябрська

\begin{tabular}{|l|c|}
\hline \multicolumn{1}{|c|}{ Об'єкт дослідження } & Кількісний вміст, \% \\
\hline Груші звичайної листя сорту Лимонка & $1,07 \pm 0,04$ \\
\hline Груші звичайної листя сорту Лісова красуня & $3,32 \pm 0,08$ \\
\hline Груші звичайної листя сорту Ноябрська & $3,01 \pm 0,07$ \\
\hline
\end{tabular}


ВИСНОВКИ. 1. Проведено якісне та кількісне визначення арбутину в груші звичайної листі сортів Лимонка, Лісова красуня та Ноябрська.

2. Одержані результати показали, що перспективною сировиною для одержання арбутину $\epsilon$ груші звичайної листя сортів Лісова красуня та Ноябрська.

\section{СПИСОК ЛІТЕРАТУРИ}

1. Стратегія лікування неускладнених інфекцій нижніх сечовивідних шляхів / В. М. Григоренко, О.В.Ромащенко, В.В.Білоголовська, С.С.Волков // Новости медицины и фрармации в Украине. - 2016. № 11 (585). - С. 40-44.

2. Білоруський Б. О. Сучасні підходи до лікування хронічного циститу у жінок / Б. О. Білоруський, О. О. Строй // Ліки України. - 2017. - № 5 (211). C. 33-35.

3. Пасєчніков С. П. Цистит: етіопатогенез, класисрікація, клінічна картина, діагностика, лікування / С. П. Пасєчніков // Укр. мед. часоп. - 2016. - № 4. C. $1-4$.

4. Нікітін О. Д. Сучасна фрітотерапія гострого циститу / О. Д. Нікітін // Семейная медицина. - 2014. № 6 (56). - С. 8-12.

5. Волобой Н. Л. Сравнение мочегонной активности арбутина и гидрохинона при различных способах введения в эксперименте на крысах / Н. Л. Волобой, И. В. Смирнов, А. А. Бондарев // Нефрология. 2012. - 16, № 4. - C. 84-87.

6. Chemical Information Review Document for Arbutin and Extracts from Arctostaphylos uva-ursi. Supporting Nomination for Toxicological Evaluation by the National Toxicology Program. - 2016. - 38 p.

\section{REFERENCES}

1. Hryhorenko, V.M., Romashchenko, O.V., Biloholovska, V.V., \& Volkov, S. S. (2016). Stratehiia likuvannia neuskladnenykh infektsii nyzhnikh sechovyvidnykh shliakhiv [A strategy for the treatment of uncomplicated infections of the lower urinary tract]. Novosti meditsyny $i$ farmatsii v Ukraine - News of Medicine and Pharmacy, 11(585), 40-44 [in Ukrainian].

2. Biloruskyi B.O., \& Stroi, O.O. (2017). Suchasni pidkhody do likuvannia khronichnoho tsystytu u zhinok [Current approaches to the treatment of chronic cystitis in women]. Liky Ukrainy - Medicines of Ukraine, 5 (211), 33-35 [in Ukrainian].

3. Pasiechnikov, S.P. (2016). Tsystyt: etiopatohenez, klasyfikatsiia, klinichna kartyna, diahnostyka, likuvannia [Cystitis: etiopathogenesis, classification, clinical picture,
3. Одержані експериментальні дані буде використано при стандартизації груші звичайної листя, розробці методів контролю якості на досліджувану сировину, а також одержанні срармакологічно активних субстанцій на їі основі.

7. Волобой Н. Л. Изучение антимикробного действия арбутина и гидрохинона в отношении некоторых представителей грамотрицательной срлоры / Н. Л. Волобой, Л. Ю. Бутакова, И. В. Смирнов // Химия растительного сырья. - 2013. - № 1. - С. 179-182.

8. Антиоксидантный и прооксидантный эфффекты арбутина и гидрохинона в эксперименте in vitro / Н. Л. Волобой, Я. Ф. Зверев, В. М. Брюханов [и др.] // Бюлл. Сибир. медицины. - 2011. - № 5. - С. 41-44.

9. Новосел О. М. Фармакогностичне вивчення представників родів Malus та Pyrus : дис. ... канд. фрармац. наук : 15.00.02 / Новосел О. М. ; НФаУ. - Х., 2007. - 232 c.

10. Державна Фармакопея України : у 3 т. / ДП “Укр. наук. фрармакоп. центр якості лік. засобів". -2-ге вид. X. : Укр. наук. фрармакоп. центр якості лік. засобів, 2014. - 3. - 732 c.

11. Дослідження френольних сполук спиртового екстракту з листя брусниці звичайної / М. А. Комісаренко, А. С. Гейдерих, А. М. Ковальова, О. М. Кошовий // Укр. журн. клініч. та лаб. медицини. - 2012. - 7, № 2. - C. 24-26.

12. Маркарян А. А. Хроматографическое изучение френольного состава сухого экстракта "Несросрит" / А. А. Маркарян, А. А. Абрамов // Вестн. Москов. ун-та. Серия 2 "Химия". - 2013. - 44, № 5. - С. 356-360.

diagnosis, treatment]. Ukrainskyi medychnyi chasopys Ukrainian Medical Bulletin, 4, 1-4 [in Ukrainian].

4. Nikitin, O.D. (2014). Suchasna fitoterapiia hostroho tsystytu [Modern phytotherapy of acute cystitis]. Semeynaya meditsyna - Family Medcine, 6 (56), 8-12 [in Ukrainian].

5. Voloboy, N.L., Smirnov, I.V., \& Bondarev, A.A. (2012). Sravnenie mochegonnoy aktivnosti arbutina i gidrokhinona pri razlichnykh sposobakh vvedeniya $v$ eksperimente na krysakh [Comparison of diuretic activity of arbutin and hydroquinone in different methods of administration in a rat experiment]. Nefrologiya - Nephrology, 16 (4), 84-87 [in Russian].

6. (2016). Chemical Information Review Document for Arbutin and Extracts from Arctostaphylos uva-ursi. 
Supporting Nomination for Toxicological Evaluation by the National Toxicology Program.

7. Voloboy, N.L., Butakova, L.Yu., \& Smirnov, I.V. (2013). Izuchenie antimikrobnogo deystviya arbutina i gidrokhinona $v$ otnoshenii nekotorykh predstaviteley gramotritszatelnoy flory [The study of the antimicrobial action of arbutin and hydroquinone against some members of the gram-negative flora]. Khimiya rastitelnogo syrya - Chemistry of Plant Raw Material, 1, 179-182 [in Russian].

8. Voloboy, N.L., Zverev, Ya.F., \& Bryukhanov, V.M. (2011). Antioksidatnyy i prooksidantnyy effekty arbutina i gidrokhinona $v$ eksperimente in vitro [Antioxidant and prooxidant effects of arbutin and hydroquinone in an in vitro experiment]. Byulleten sibirskoy meditsiny-Bulletin of Siberian Medicine, 5, 41-44 [in Russian].

9. Novosel, O.M. (2007). Farmakohnostychne vyvchennia predstavnykiv rodiv Malus ta Pyrus [Pharmacognostic study of representatives of the genera Malus and Pyrus]. Candidate's thesis. Kharkiv: NFaU [in Ukrainian].

10. (2014). Derzhavna Farmakopeia Ukrainy: u $3 t$. [State Pharmacopoeia of Ukraine: in 3 vol.]. Kharkiv: Ukr. nauk. farmakop. tsentr yakosti lik. zasobiv [in Ukrainian].

11. Komisarenko, M.A., Heiderykh, A.S., Kovalova, A.M., \& Koshovyi, O.M. (2012). Doslidzhennia fenolnykh spoluk spyrtovoho ekstraktu z lystia brusnytsi zvychainoi [Investigation of phenolic compounds of alcoholic extract from cranberry leaves]. Ukrainskyi zhurnal klinichnoi ta laboratornoi medytsyny - Ukrainian Journal of Clinical and Laboratory Medicine, 7 (2), 24-26 [in Ukrainian].

12. Markaryan, A.A., \& Abramov, A.A. (2013). Khromatograficheskoe izuchenie fenolnogo sostav sukhogo ekstrakta "Nefrofit" [Chromatographic study of the phenolic composition of the dry extract: Nephrophyte"]. Vestnik Moskovskogo universiteta. Seriya 2. Khimiya Bulletin of Moscow University. Series 2. Chemistry, 44 (5), 356-360 [in Russian].

Е. Н. Новосел ${ }^{1}$, В. С. Кисличенко ${ }^{1}$, А. И. Федосов ${ }^{1}$, л. Н. Андрюкова ${ }^{1}$, А. А. Волошина ${ }^{2}$ НАЦИОНАЛЬНЫЙ ФАРМАЦЕВТИЧЕСКИЙ УНИВЕРСИТЕТ ${ }^{1}$, ХАРЬКОВ ООО "РИМ КОНСАЛТИНГ ГРУПП" , КИЕВ

\section{ОПРЕДЕЛЕНИЕ АРБУТИНА В ГРУШЕ ОБЫКНОВЕННОЙ ЛИСТЬЯХ СОРТОВ ЛИМОНКА, ЛЕСНАЯ КРАСАВИЦА И НОЯБРЬСКАЯ}

\section{Резюме}

Вступление. Цистит - одна из довольно частых нозологических форм инфекционно-воспалительных заболеваний мочевыводящих путей. Распространенность острого цистита в Украине составляет 314 на 100 тыс. населения, хронического цистита - 135 на 100 тыс. населения. Для лечения данного заболевания успешно используют лекарственное растительное сырье, которое содержит арбутин и гидрохинон, в частности сырье груши обыкновенной.

Цель исследования - обнаружить и определить количественное содержание арбутина в груши обыкновенной листьях сортов Лимонка, Лесная красавица и Ноябрьская.

Методы исследования. Объектом исследования были груши обыкновенной листья сортов Лимонка, Лесная красавица и Ноябрьская. Обнаружение арбутина проводили с помощью химических реакций и хроматографии в тонком слое сорбента. Его количественное содержание определяли спектрофротометрическим методом при длине волны 455 нм по методике Государственной Фармакопеи Украины.

Результаты и обсуждение. В результате проведенных химических реакций и хроматограсрического анализа в груши обыкновенной листьях изучаемых сортов установлено наличие арбутина. Содержание арбутина, которое было определено спектрофотометрическим методом, в груши обыкновенной листьях сортов Лимонка, Лесная красавица и Ноябрьская составило 1,07, 3,32 и 3,01 \% соответственно.

Выводы. В груши обыкновенной листьях сортов Лимонка, Лесная красавица и Ноябрьская установлено наличие и определено содержание арбутина, которое составило 1,07, 3,32 и 3,01 \% соответственно. Полученные экспериментальные данные будут использованы при стандартизации груши обыкновенной листьев, разработке методов контроля качества на исследуемое сырье, а также получении фрармакологически активных субстанций на его основе.

КЛЮЧЕВЫЕ СЛОВА: груша обыкновенная; арбутин; качественный и количественный анализ; хроматографрия; спектрометрия. 


\section{DETERMINATION OF ARBUTIN IN THE PYRUS COMMUNIS LEAVES OF THE LYMONKA, LISOVA KRASUNIA AND NOIABRSKA VARIETIES}

\section{Summary}

Introduction. Cystitis is one of the quite common nosological forms of infectious-inflammatory diseases of the urinary tract. Prevalence of acute cystitis in Ukraine is 314 per 100 thousand population, chronic cystitis - 135 per 100 thousand population. For the treatment of this disease successfully used medicinal herbal raw materials containing arbutin and hydroquinone, in particular raw pear.

The aim of the study - to identify and quantify arbutin in the pear of ordinary leaves of the Lymonka, Lisova krasunia and Noiabrska varieties.

Research Methods. The subject of the study were pears of ordinary leaves Lymonka, Lisova krasunia and Noiabrska varieties. Detection of arbutin was carried out by chemical reactions and chromatography in a thin layer of sorbent. The quantitative content was determined by spectrophotometric method at a wavelength of $455 \mathrm{~nm}$ by the method of State Pharmacopoeia of Ukraine.

Results and Discussion. As a result of the chemical reactions and chromatographic analysis, the presence of arbutin was established in the pear of the ordinary leaves of the varieties studied. The content of arbutin, determined by the spectrophotometric method, in the pear of ordinary leaves of the Lymonka, Lisova krasunia and Noiabrska varieties was $1.07 \%, 3.32 \%$ and $3.01 \%$, respectively.

Conclusions. The pear of the ordinary leaves of the Lymonka, Lisova krasunia and Noiabrska varieties established the presence and determined the content of arbutin, which amounted to $1.07 \%, 3.32 \%$ and $3.01 \%$, respectively. The obtained experimental data will be used for standardization of pear of ordinary leaves, development of quality control methods for the raw material under study, as well as preparation of pharmacologically active substances based on it.

KEY WORDS: Pyrus communis; arbutin; qualitative and quantitative analysis; chromatography; spectrometry.

Отримано 16.01.20

Адреса для листування: О. М. Новосел, Національний фрармацевтичний університет, вул. Пушкінська, 53, Харків, 61002, Україна, e-mail: lenanovosel1@ukr.net. 